\title{
Labour Force Participation and the Likelihood of Abortion in Finland over Three Birth Cohorts
}

\author{
HEINI VÄISÄNEN
}

London School of Economics and Political Science, United Kingdom

\section{Abstract}

There is a lack of studies on the association between labour force participation and abortion. This study examined how the likelihood of having an abortion depends on being employed, unemployed, student or outside the workforce using Finnish register data from three birth cohorts (born in 1955-59, 1965-69 and 1975-79) of nearly 260,000 women. The results differed depending on whether all women or only pregnant women were studied and on the cohort analysed. Unemployed women had a high likelihood of abortion when all women were studied, but among pregnant women students had the highest likelihood. The direction and strength of the association varied by relationship status, age, and parity. The results show that the likelihood of abortion depends on women's economic position. More studies on contraceptive use and pregnancy intentions in Finland are needed to identify the mechanisms behind these findings.

Keywords: Induced abortion; Finland; register data; reproductive health

\section{Introduction}

Around 10,000 abortions are performed in Finland annually. The number of abortions has declined since the peak years of the 1970s (e.g. 21,574 in 1975) (Vuori and Gissler 2013). Abortion rate (number of abortions per 1000 women aged $15-49$ years) in Finland is relatively low compared to other developed countries with liberal abortion legislation (Denisov, Sakevich, and Jasilioniene 2012). The abortion rate in high-income countries was on average 39 in 1995 and 24 in 2008, while the rate in Finland was 8 and 9, respectively (Sedgh et al. 2012).

Abortions are not evenly distributed within the female population. Studies suggest that high opportunity costs of childbearing, low socioeconomic status or education, young age, being single or having relationship problems, and previous births and abortions increase the probability of abortion in Europe and US (Bankole, Singh, and Haas 1998; Jones, Darroch, and Henshaw 2002; Rossier, Michelot, and Bajos 2007), the Nordic Countries (e.g. Knudsen et al. 2003; Rasch et al. 2007) and in Finland (Heikinheimo, Gissler, and Suhonen 2008; Lehti et al. 2013; Niinimäki et al. 2009; Regushevskaya et al. 2009; Väisänen and Jokela 2010; Väisänen 2015). However, there is a lack of studies investigating the relationship between labour force participation and the likelihood of having an abortion, and whether it has changed over time. The likelihood of abortion 
may differ by labour force participation status because women in difficult economic positions often want to postpone childbearing until their situation improves (Hrdy 1999) or women may wish to avoid opportunity costs of childbearing (Becker 1991) in particular if they have high education (Kreyenfeld 2010). In Finland, young women chose to postpone their childbearing during the recession in the 1990s while waiting for a more stable economic situation (Lainiala 2014). Students may find it particularly hard to start childbearing regardless of the macro-economic environment, since the basic maternity leave allowance is low (currently $€ 24$ per working day (KELA 2015)) and the allowance reduces their student benefit. Women on temporary employment contracts postpone childbearing not because they are worried about their financial wellbeing, but because they are concerned about their future career prospects (Sutela 2013).

The relationship between economic uncertainty and likelihood of abortion is not independent of the wider context of women's lives. For instance, having a partner with a stable labour market position may encourage some women to have children despite their own uncertain status, and the number of children they already have interacts with their views on a suitable timing for childbearing. Moreover, strong motivation to avoid childbearing is associated with consistent contraceptive use (Frost, Singh, and Finer 2007; Moreau et al. 2013), which in turn is negatively associated with likelihood of unintended pregnancy. Whether a woman decides to terminate an unintended pregnancy depends partly on her attitudes towards abortion and whether she sees the pregnancy being sustainable at that time (Coast et al. 2014).

The aim of this study is to examine whether the likelihood of an abortion differs depending on whether the woman is employed, unemployed, student or outside the workforce (e.g. on maternity leave, pension or military service). I analyse Finnish register data from three birth cohorts (born in 1955-59, 1965-69 and 1975-79). Register data is more reliable than survey data, since registers do not suffer from underreporting of abortion (Jones and Kost 2007) or attrition. The analyses are conducted at three points in time: when the women were approximately 20,25 and 30 years old.

\section{Data and methods}

The study uses nationally representative data on three female birth cohorts (born in 195559, 1965-69 and 1975-79). Information about births and abortions were obtained from the Register of Induced Abortions and the Medical Birth Register whenever possible. As the Medical Birth Register has only existed since 1987, information of life births before that year were obtained from Population Information System, into which all live births in Finland are registered (Gissler 2010; Population Register Centre 2015). Statistics Finland compiled other socio-demographic information from their own sources, such as Statistics Finland's Register of Completed Education and Degrees (Statistics Finland 2011). Permission to use and link these data were obtained from Statistics Finland and the National Institute of Health and Welfare. 
These data were collected using two-stage sampling. First, an 80 per cent random sample of all the women of the above mentioned cohorts, who had had at least one abortion within the fertile period of their life (assumed to be ages 15-50) were collected $(\mathrm{N}=91,636)$. An 80 per cent sample was collected since the ethics regulations of Statistics Finland did not allow for using a higher proportion of the population. Second, a comparison group, twice the size of the study group, of women from the same cohorts who had not had an abortion, were selected using random sampling $(\mathrm{N}=183,272)$. The sample was taken from the group of women who had lived in Finland for at least a year within any of the following periods: $1970-75,1980-85$ or 1987-2010 and had not had an abortion during their stay in Finland. These periods were chosen, because these were the years when detailed information on the Finnish population was available. In the statistical analysis weights were used to control for this design. Overall the unweighted sample includes almost half of the women of these three cohorts.

The dataset includes information on induced abortions, live births, labour force participation (employed, unemployed, student, and "outside workforce" ${ }^{1}$ ), relationship status (single, cohabiting, married, divorced, or widowed - the latter two were combined in the analyses, since there were few widowed women in the sample), place of residence (level of urbanisation: urban, semi-urban or rural, and province: South, West, East, North, Lapland, and Åland), immigration status (someone born in Finland and speaking Finnish or Swedish as her native language is considered a native Finn, nonnative otherwise), and education, which was classified as low education (only completed compulsory schooling); middle (upper secondary degree); and high (tertiary education). Since education had been coded as missing for anyone with less than upper secondary schooling in my dataset due to ethical regulations, I assumed that these women only had completed compulsory education. I also created a variable which approximates the macro-economic environment specific to the age group and year in the sample by dividing the number of unemployed women by the number of employed women and multiplying the result by 100 called "sample unemployment" and to be used as a control variable in the multivariate analysis.

The dataset includes the following time-varying variables. Year and month of abortions and live births; changes in marital status updated once a year; cohabitation included annually since 1987, but not at all before that; labour force participation and level of

1 Although these statuses mostly describe the women's labour market situation correctly, there are a few caveats to keep in mind. Statistics Finland classifies students who work (part- or full-time) as "employed". Women on maternal leave who have a job waiting for them have been classified as "employed", whereas those who do not have been classified as "outside workforce". Some women on maternal leave may be classified as students, if that is their main type of activity rather than taking care of their children at home. Women who stay home for long periods of time (e.g. use child care leave allowing to stay at home until their youngest child is three years old) are typically classified as "outside workforce". (Official Statistics of Finland 2012; Official Statistics of Finland 2013b). Thus, most of those outside workforce in this study are likely to be women taking long periods of time off work to take care of their children at home. 
education measured at ages 20,25 and 30 or the nearest year possible, as information on these variables were recorded in the Population register every five years (census years 1970, 1975 etc.) until year 1987 after which the variables have been recorded annually.

The three time points when labour force participation was measured (approximate ages of 20,25 and 30) were included in the analysis. Since labour force participation was recorded based on activity on the last week of the year (Official Statistics of Finland 2013a), the incidence of abortions was measured on the following year, that is, if labour force participation status was measured at age 20, abortions were measured on the year the woman turned 21 etc. Births were included from April the following year until March the year after that in order to exclude last trimester pregnancies at the time of measuring the labour force status, because at these late stages the pregnancy may already affect the labour force status, and the purpose was to avoid reverse association (pregnancy outcome being associated with future labour force status rather than vice versa). In the text, the first point in time the analysis was conducted is referred to as age 20 , the second as age 25 and the third as age 30 although sometimes this is only the approximate age.

These data were analysed using descriptive statistics and logistic regression. The outcome variable was having an abortion. Although the motivation to have an abortion is likely to be different depending on whether it was due to medical or social indication and may differ depending on whether it is the first or a repeat abortion, all abortions were included in order to maximise the number of outcome events. The standard errors in the logistic models were robust and took into account the longitudinal nature of the data. The models were conducted separately for each cohort because the effects of the covariates may depend on cohort. The models were first conducted for all women to get an understanding of the levels of risk in the general population, and then only to women who became pregnant during the study period in order to focus the analysis on the women who were at risk of having an abortion (excluding women who had a miscarriage, since information on spontaneous pregnancy loss was not included in the dataset).

The main explanatory variable-labour force participation - was first analysed together with age. Next, all the other covariates (age, relationship status, education, parity, place of residence, and immigration status) were added to the models. A variable of years since previous birth was also added into the model for pregnant women. Finally, the covariate of interest, labour force participation, was interacted with relationship status, parity, education and age in order to see whether its association with the outcome varies with these main explanatory variables. The interactions that were significant at 5\% level in joint Wald tests of the hypothesis that all of the categories of the interaction term have no association with the outcome were included in the final models. These effects were illustrated using a marginal probabilities at representative values approach (Williams 2012).

I conducted a model where data from all cohorts were pooled and cohort effect was added as one of the covariates and interacted with all other covariates in order to test 
the statistical significance of the cohort differences (results not shown). Among all women, all interactions between cohort and the main effects of age, partnership status, education and labour market status were statistically significant at $1 \%$ level. Among pregnant women, all interactions between cohort and the main effects of age, partnership status and labour market status were statistically significant at $1 \%$ level, but the interaction between education and cohort was not. The main effect of cohort was statistically significant at $0.1 \%$ level in both models. Thus, the cohort differences presented in the paper are statistically significant. All analyses were conducted in Stata version 13.

\section{Results}

Most women were employed at all stages of the study, ranging from 31 to 56 percent at age 20, 60 to 71 percent at age 25, and 66 to 80 percent at age 30 depending on cohort (Table 1). Almost half of women aged 20 were students in the latest cohort, compared to around one-third in the other two cohorts. Less than five percent of women were unemployed in the earliest cohort at all ages, but between seven and thirteen percent of women were unemployed in the other two cohorts at each time point. The rest of the women were outside the workforce.

Table 1. Descriptive statistics: weighted \% and unweighted N.

1a) Cohort 1955-59

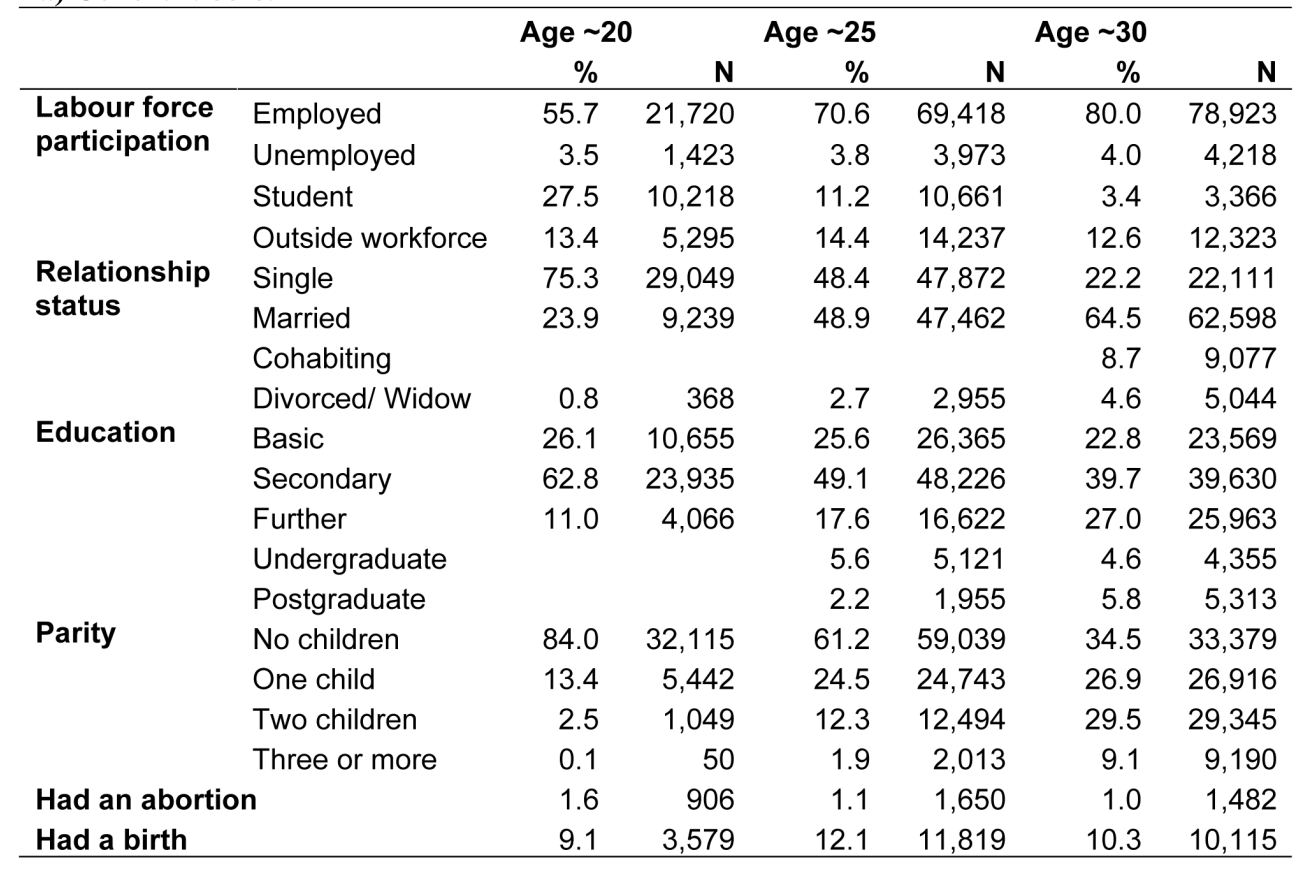


1b) Cohort 1965-69

\begin{tabular}{|c|c|c|c|c|c|c|c|}
\hline \multicolumn{8}{|c|}{ Age $\sim 25$} \\
\hline & & $\%$ & $\mathbf{N}$ & $\%$ & $\mathbf{N}$ & $\%$ & $\mathbf{N}$ \\
\hline \multirow{4}{*}{$\begin{array}{l}\text { Labour force } \\
\text { participation }\end{array}$} & Employed & 51.5 & 49,337 & 59.7 & 56,418 & 65.6 & 61,951 \\
\hline & Unemployed & 7.2 & 7,084 & 12.4 & 12,198 & 13.0 & 12,978 \\
\hline & Student & 34.4 & 31,194 & 15.7 & 14,506 & 6.5 & 6,226 \\
\hline & Outside workforce & 6.9 & 6,826 & 12.2 & 12,000 & 15.0 & 14,325 \\
\hline \multirow{4}{*}{$\begin{array}{l}\text { Relationship } \\
\text { status }\end{array}$} & Single & 83.2 & 77,910 & 38.0 & 36,041 & 23.4 & 22,683 \\
\hline & Married & 6.2 & 6,055 & 30.8 & 28,722 & 49.2 & 45,643 \\
\hline & Cohabiting & 10.5 & 10,362 & 29.7 & 28,736 & 23.3 & 22,782 \\
\hline & Divorced/ Widow & 0.1 & 114 & 1.5 & 1,623 & 4.1 & 4,372 \\
\hline \multirow[t]{5}{*}{ Education } & Basic & 22.3 & 22,626 & 16.0 & 16,675 & 14.3 & 14,932 \\
\hline & Secondary & 76.1 & 70,289 & 70.4 & 66,298 & 49.3 & 47,367 \\
\hline & Further & 1.6 & 1,526 & 7.6 & 6,904 & 20.9 & 19,463 \\
\hline & Undergraduate & & & 2.7 & 2,346 & 4.3 & 3,886 \\
\hline & Postgraduate & & & 3.4 & 2,899 & 11.2 & 9,832 \\
\hline \multirow[t]{4}{*}{ Parity } & No children & 96.2 & 90,406 & 74.6 & 69,379 & 43.6 & 40,602 \\
\hline & One child & 3.5 & 3,700 & 16.2 & 16,316 & 23.3 & 22,571 \\
\hline & Two children & 0.3 & 329 & 7.7 & 7,916 & 24.1 & 23,320 \\
\hline & Three or more & 0.0 & 6 & 1.5 & 1,511 & 9.1 & 8,987 \\
\hline \multicolumn{2}{|c|}{ Had an abortion } & 2.0 & 2,767 & 1.3 & 1,840 & 1.2 & 1,675 \\
\hline \multicolumn{2}{|l|}{ Had a birth } & 4.8 & 4,927 & 12.8 & 12,115 & 11.4 & 10,749 \\
\hline
\end{tabular}

1c) Cohort 1975-79

\begin{tabular}{|c|c|c|c|c|c|c|c|}
\hline & & \multicolumn{2}{|c|}{ Age $\sim 20$} & Age $\sim 25$ & \multicolumn{3}{|c|}{ Age $\sim 30$} \\
\hline & & $\%$ & $\mathbf{N}$ & $\%$ & $\mathbf{N}$ & $\%$ & $\mathbf{N}$ \\
\hline \multirow{4}{*}{$\begin{array}{l}\text { Labour force } \\
\text { participation }\end{array}$} & Employed & 31.4 & 18,288 & 63.2 & 36,000 & 74.3 & 43,033 \\
\hline & Unemployed & 13.2 & 8,222 & 8.4 & 5,394 & 6.8 & 4,426 \\
\hline & Student & 47.3 & 25,945 & 16.9 & 9,529 & 6.1 & 3,696 \\
\hline & Outside workforce & 8.1 & 5,257 & 11.5 & 7,151 & 12.8 & 7,556 \\
\hline \multirow{4}{*}{$\begin{array}{l}\text { Relationship } \\
\text { status }\end{array}$} & Single & 71.7 & 40,416 & 40.7 & 23,663 & 24.2 & 14,537 \\
\hline & Married & 3.9 & 2,350 & 21.8 & 12,327 & 45.1 & 25,199 \\
\hline & Cohabiting & 24.3 & 14,887 & 36.4 & 21,276 & 27.7 & 16,765 \\
\hline & Divorced/ Widow & 0.1 & 59 & 1.1 & 808 & 3.1 & 2,210 \\
\hline \multirow[t]{5}{*}{ Education } & Basic & 17.5 & 12,319 & 11.5 & 8,325 & 10.4 & 7,352 \\
\hline & Secondary & 54.6 & 30,222 & 54.3 & 31,812 & 39.1 & 24,417 \\
\hline & Further & 27.9 & 15,171 & 10.5 & 5,837 & 8.6 & 4,890 \\
\hline & Undergraduate & & & 17.8 & 9,239 & 25.0 & 13,558 \\
\hline & Postgraduate & & & 5.9 & 2,861 & 16.9 & 8,494 \\
\hline \multirow[t]{4}{*}{ Parity } & No children & 96.7 & 55,143 & 78.8 & 43,575 & 51.2 & 28,224 \\
\hline & One child & 3.0 & 2,330 & 13.3 & 9,022 & 21.9 & 13,375 \\
\hline & Two children & 0.3 & 230 & 6.4 & 4,447 & 19.1 & 11,951 \\
\hline & Three or more & 0.0 & 9 & 1.5 & 1,030 & 7.8 & 5,161 \\
\hline \multicolumn{2}{|c|}{ Had an abortion } & 1.5 & 1972 & 1.3 & 1,648 & 0.8 & 1,052 \\
\hline \multicolumn{2}{|l|}{ Had a birth } & 4.7 & 3,180 & 10.0 & 5,981 & 12.4 & 7,040 \\
\hline
\end{tabular}


Although most women were single in the youngest age group (72-83 percent depending on cohort), many got married by age 30 (45-65 percent depending on cohort). In the earliest cohort, women aged 20 or 25 who were cohabiting were classified as single, because information on cohabitation has only been available in the registers since 1987. The level of education increased over time. Although a fifth of women had only completed compulsory education in the earliest cohort, only one in ten had this level of education in the 1970s cohort. Most women had no children at age 20 (84-97 percent depending on cohort), but by age 30 around a half of women in the two latest cohorts and two-thirds in the earliest cohort had had at least one child. In each age and cohort group one to two percent of women had an abortion during the study time, whereas between five and 13 percent had a birth (Table 1).

Table 2 shows analyses of the likelihood of abortion among all women using logistic regression. The unemployed had 58-84 percent higher odds of abortion that employed women in the age-controlled models depending on cohort, which declined to 25-50 percent higher odds after the other variables were controlled for. Students did not differ from employed women statistically significantly in the earliest cohort, but had 23-24 percent lower odds of abortion in the other two in the multivariate models. Although women outside workforce had higher odds of abortion than employed women in the age controlled models (24-77 percent depending on cohort), the association disappeared in the 1970s cohort when other covariates were controlled for. In the other two cohorts they still had 11-20 percent higher odds. Other covariates were also associated with increased odds of experiencing an abortion, including young age, not having a partner, low education, high parity, not being a native Finn and living in an urban area.

Table 3 shows the results of age-controlled and multivariate main effects models among women who experienced a pregnancy during the study period. In this group, students had the highest likelihood of abortion in all cohorts after controlling for all covariates: the odds were 34-95 percent higher than for employed women depending on cohort. Contrary to the model where all women were studied, unemployed women were not distinguishable from employed women in the 1970s cohort after all covariates were controlled for, but in the other two cohorts their odds of abortion were 37-52 percent higher compared to employed women. When it comes to other covariates in the models, the associations were similar to the models which included all women: young age, not having a partner, low education and high parity not being a native Finn and living in an urban area were associated with increased likelihood of an abortion. 
Table 2. Logistic regression models for all women, main effects only.

$\begin{array}{llll}\text { Cohort } & 1955-59 & 1965-69 & 1975-79\end{array}$
(1)
(1)
(2)
(1)
(2)

\begin{tabular}{|c|c|c|c|c|c|c|}
\hline \multicolumn{7}{|l|}{ Labour market status } \\
\hline Employed & 1.00 & 1.00 & 1.00 & 1.00 & 1.00 & 1.00 \\
\hline Unemployed & $1.84^{* * *}$ & $1.50^{* * *}$ & $1.58^{* * *}$ & $1.26^{* \star *}$ & $1.69^{* * *}$ & $1.25^{\star * *}$ \\
\hline Student & 0.91 & 0.96 & $0.76^{* * *}$ & $0.76^{* * *}$ & $0.89^{* *}$ & $0.77^{* * *}$ \\
\hline Outside workforce & $1.24^{* \star *}$ & $1.11^{*}$ & $1.67^{* \star *}$ & $1.20^{\star * *}$ & $1.79^{* * *}$ & 0.95 \\
\hline \multicolumn{7}{|l|}{ Age } \\
\hline$\sim 20$ & 1.00 & 1.00 & 1.00 & 1.00 & 1.00 & 1.00 \\
\hline$\sim 25$ & $0.69^{* * *}$ & $0.68^{* * *}$ & $0.59^{* * *}$ & $0.64^{\star * *}$ & $0.81^{\star * *}$ & $0.70^{* * *}$ \\
\hline$\sim 30$ & $0.61^{* * *}$ & $0.55^{* \star *}$ & $0.52^{* \star *}$ & $0.48^{\star \star *}$ & $0.52^{* \star *}$ & $0.38^{\star \star *}$ \\
\hline $\begin{array}{l}\text { Sample unemployment } \\
\text { Relationship status }\end{array}$ & & $0.94^{* *}$ & & 1.00 & & $0.68^{* *}$ \\
\hline Single & & 1.00 & & 1.00 & & 1.00 \\
\hline Married & & $0.36^{* * *}$ & & $0.37^{* * *}$ & & $0.44^{* * *}$ \\
\hline Cohabiting & & $0.62^{* * *}$ & & $0.64^{* * *}$ & & $0.69^{* \star *}$ \\
\hline Divorced & & $1.19^{*}$ & & 1.10 & & 1.04 \\
\hline \multicolumn{7}{|l|}{ Education } \\
\hline Low & & 1.00 & & 1.00 & & 1.00 \\
\hline Middle & & $0.75^{* * *}$ & & $0.55^{\star * *}$ & & $0.43^{* * *}$ \\
\hline High & & $0.45^{* * *}$ & & $0.27^{\star * *}$ & & $0.27^{\star * *}$ \\
\hline \multicolumn{7}{|l|}{ Parity } \\
\hline No children & & 1.00 & & 1.00 & & 1.00 \\
\hline One child & & $1.94^{* * *}$ & & $2.49^{\star \star *}$ & & $2.69^{* \star *}$ \\
\hline Two children & & $2.57^{\star * *}$ & & $2.87^{\star \star \star}$ & & $3.05^{\star \star *}$ \\
\hline Three or more & & $3.65^{* * *}$ & & $3.42^{\star * *}$ & & $3.74^{* * *}$ \\
\hline Not native & & $1.78^{* * *}$ & & $1.40^{* * *}$ & & $1.34^{* * *}$ \\
\hline \multicolumn{7}{|l|}{ Province } \\
\hline South & & 1.00 & & 1.00 & & 1.00 \\
\hline West & & $0.80^{\star * *}$ & & $0.81^{* * *}$ & & 0.95 \\
\hline East & & $0.88^{*}$ & & $0.84^{* * *}$ & & 0.99 \\
\hline Oulu & & $0.72^{* * *}$ & & $0.81^{* * *}$ & & 0.95 \\
\hline Lapland & & 0.90 & & $1.22^{\star *}$ & & $1.26^{\star *}$ \\
\hline Aland & & 0.53 & & 0.78 & & 1.32 \\
\hline \multicolumn{7}{|l|}{ Level of urbanisation } \\
\hline Urban & & 1.00 & & 1.00 & & 1.00 \\
\hline Semi-Urban & & 0.93 & & $0.81^{* * *}$ & & $0.84^{* * *}$ \\
\hline Rural & & $0.76^{* * *}$ & & $0.75^{\star \star *}$ & & $0.78^{* * *}$ \\
\hline
\end{tabular}

(1) Age-controlled model; (2) Multivariate model

Notes: As information on cohabitation has only been available since 1987 in the registers, its estimates for the earliest cohort are only indicative. 
Table 3. Logistic regression models for pregnant women, main effects only.

\begin{tabular}{|c|c|c|c|c|c|c|}
\hline \multirow[t]{2}{*}{ Cohort } & \multicolumn{2}{|l|}{$1955-59$} & \multicolumn{2}{|l|}{$1965-69$} & \multicolumn{2}{|l|}{$1975-79$} \\
\hline & (1) & $(2)$ & (1) & $(2)$ & $(1)$ & $(2)$ \\
\hline \multicolumn{7}{|l|}{ Labour force participation } \\
\hline Employed & 1.00 & 1.00 & 1.00 & 1.00 & 1.00 & 1.00 \\
\hline Unemployed & $2.04^{* * *}$ & $1.52^{* * *}$ & $1.45^{* * *}$ & $1.11^{*}$ & $1.37^{* * *}$ & 0.93 \\
\hline Student & $1.98^{* * *}$ & $1.95^{\star \star *}$ & $2.21^{* \star *}$ & $1.85^{\star \star \star}$ & $1.72^{\star * \star}$ & $1.34^{\star * *}$ \\
\hline Outside workforce & $1.29^{* * *}$ & $1.20^{* *}$ & $1.43^{* * *}$ & $1.39^{* * *}$ & $1.20^{* * *}$ & 1.04 \\
\hline \multicolumn{7}{|l|}{ Age } \\
\hline$\sim 20$ & 1.00 & 1.00 & 1.00 & 1.00 & 1.00 & 1.00 \\
\hline$\sim 25$ & $0.57^{\star \star \star}$ & $0.71^{\star \star *}$ & $0.25^{\star \star \star}$ & $0.50^{* \star \star}$ & $0.44^{\star \star \star}$ & $0.66^{\star \star \star}$ \\
\hline$\sim 30$ & $0.62^{* * *}$ & $0.76^{* * *}$ & $0.27^{* * *}$ & $0.45^{* * *}$ & $0.24^{* * *}$ & $0.43^{* * *}$ \\
\hline $\begin{array}{l}\text { Sample unemployment } \\
\text { Relationship status }\end{array}$ & & 0.98 & & $0.99^{* *}$ & & 0.94 \\
\hline Single & & 1.00 & & 1.00 & & 1.00 \\
\hline Married & & $0.13^{\star * *}$ & & $0.089^{* * *}$ & & $0.086^{\star * *}$ \\
\hline Cohabiting & & $0.24^{* * *}$ & & $0.22^{* * *}$ & & $0.20^{\star * *}$ \\
\hline Divorced & & $0.71^{* * *}$ & & $0.58^{* * *}$ & & $0.56^{\star * *}$ \\
\hline \multicolumn{7}{|l|}{ Education } \\
\hline Low & & 1.00 & & 1.00 & & 1.00 \\
\hline Middle & & $0.77^{\star * *}$ & & $0.83^{* * *}$ & & $0.78^{* * *}$ \\
\hline High & & $0.41^{* * *}$ & & $0.39^{* * *}$ & & $0.44^{* * *}$ \\
\hline \multicolumn{7}{|l|}{ Parity } \\
\hline No children & & 1.00 & & 1.00 & & 1.00 \\
\hline One child & & 1.13 & & $1.16^{*}$ & & 1.00 \\
\hline Two children & & $2.99^{\star \star *}$ & & $2.58^{* \star *}$ & & $2.15^{\star \star \star}$ \\
\hline Three or more & & $4.35^{\star \star \star}$ & & $3.26^{* \star \star}$ & & $2.52^{\star \star \star}$ \\
\hline Years since last birth & & $1.08^{* * *}$ & & $1.09^{* * *}$ & & $1.06^{* * *}$ \\
\hline Not native & & $1.51^{*}$ & & $1.66^{* * *}$ & & $1.46^{* * *}$ \\
\hline \multicolumn{7}{|l|}{ Province } \\
\hline South & & 1.00 & & 1.00 & & 1.00 \\
\hline West & & $0.73^{\star \star \star}$ & & $0.73^{* * *}$ & & $0.88^{*}$ \\
\hline East & & $0.84^{* *}$ & & $0.76^{* * *}$ & & $0.85^{*}$ \\
\hline Oulu & & $0.61^{\star \star *}$ & & $0.61^{* \star *}$ & & $0.78^{\star * *}$ \\
\hline Lapland & & $0.75^{* *}$ & & 0.90 & & 0.96 \\
\hline Aland & & $0.38^{\star *}$ & & $0.62^{*}$ & & 1.53 \\
\hline \multicolumn{7}{|l|}{ Level of urbanisation } \\
\hline Urban & & 1.00 & & 1.00 & & 1.00 \\
\hline Semi-Urban & & $0.84^{* *}$ & & $0.74^{* * *}$ & & $0.78^{* * *}$ \\
\hline Rural & & $0.68^{\star \star \star}$ & & $0.68^{\star \star \star}$ & & $0.70^{\star * \star}$ \\
\hline
\end{tabular}

${ }^{*} p<0.05,{ }^{* *} p<0.01,{ }^{* * *} p<0.001$

(1) Age-controlled model; (2) Multivariate model

Notes: As information on cohabitation has only been available since 1987 in the registers, its estimates for the earliest cohort are only indicative. 
Labour force participation did not interact with relationship status, parity, education or age in the 1950s cohort models for all women at five percent significance level, but it did with relationship status and age in the 1960s cohort and also education in the1970s cohort (Figure 1).

Figure 1. Marginal probabilities (\%) of abortion: significant interaction effects among all women with $95 \%$ CIs, controlling for other variables in the model, as shown in Table 2.
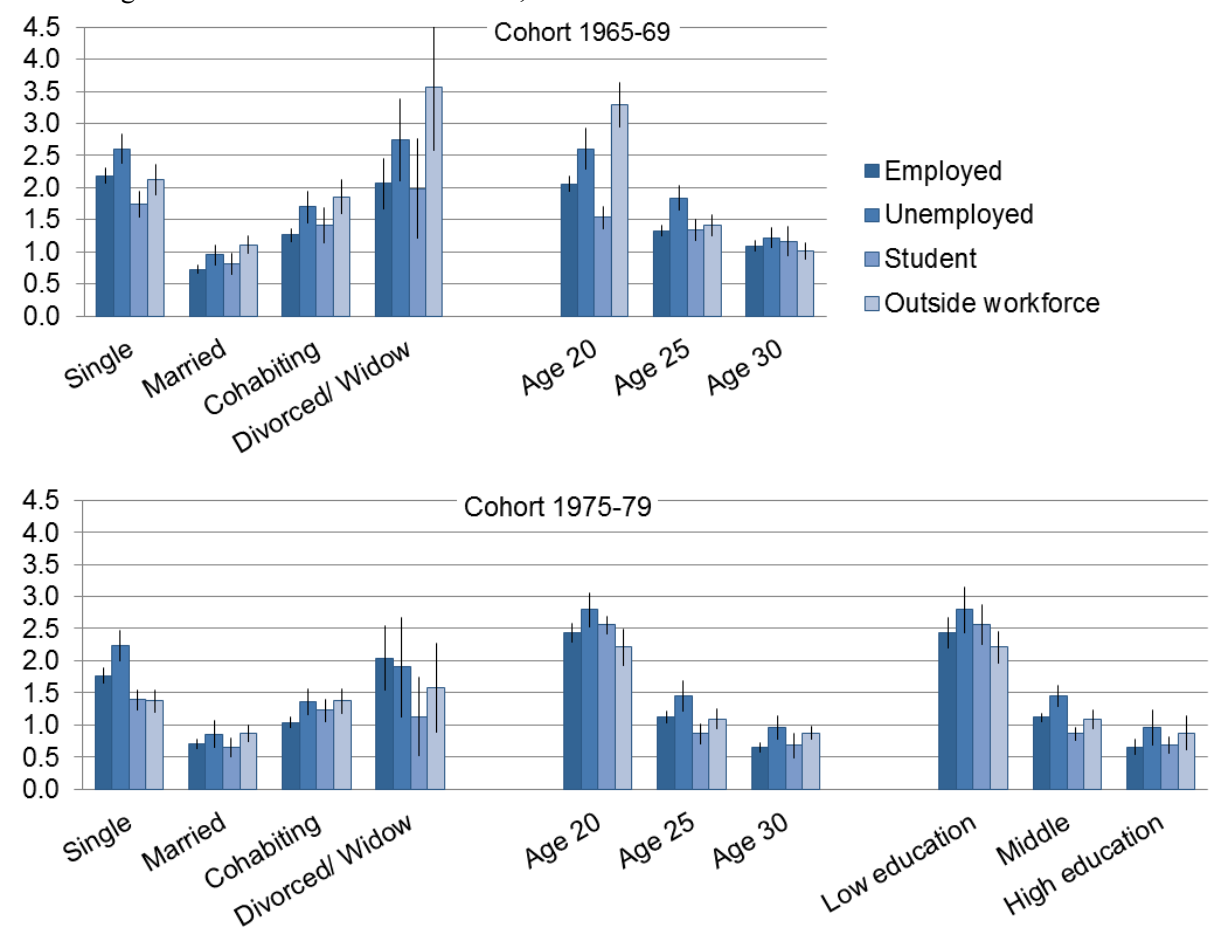

Women, who were born in the 1960s and were unemployed or outside the workforce, had the highest probability of abortion in all relationship status groups, but the probability was higher for those without a partner than those married or cohabiting. For instance, single unemployed women had slightly less than three percent probability of abortion compared to less than one percent among married unemployed women. Although the differences by labour force status were small among women in their 30s, young women (age 20 ) who were outside the workforce or unemployed had higher probability of abortion (more than 2.5 percent) than women in the other labour force status groups (two percent or less).

In the 1970s cohort, single and divorced or widowed women who were employed or unemployed had higher probability of abortion than students and those outside the workforce (Figure 1). There were no big differences by labour force status among married and cohabiting women. Like in the 1960s cohort, there were only modest differences in the probability among women aged 30 , but when the women were a decade younger, 
the probability was particularly high if they were unemployed or students (around 2.5 percent). Among women with low education, the probability was high in all labour force status groups (approximately 2-3 percent), but 1.5 percent or less in other educational groups. Interestingly, among women with low education students had the second highest probability of abortion although in other educational groups it was as low as or lower than that of employed women.

When only women who experienced a pregnancy were studied, the interactions of labour force status with relationship status and parity were significant in all cohorts. In addition, the interaction of labour force status with age was significant in the 1960s cohort, and with education in the 1970s cohort (Figure 2).

Figure 2. Marginal probabilities of abortion: significant interaction effects among pregnant women with $95 \%$ CIs, controlling for other variables in the model, as shown in Table 3.
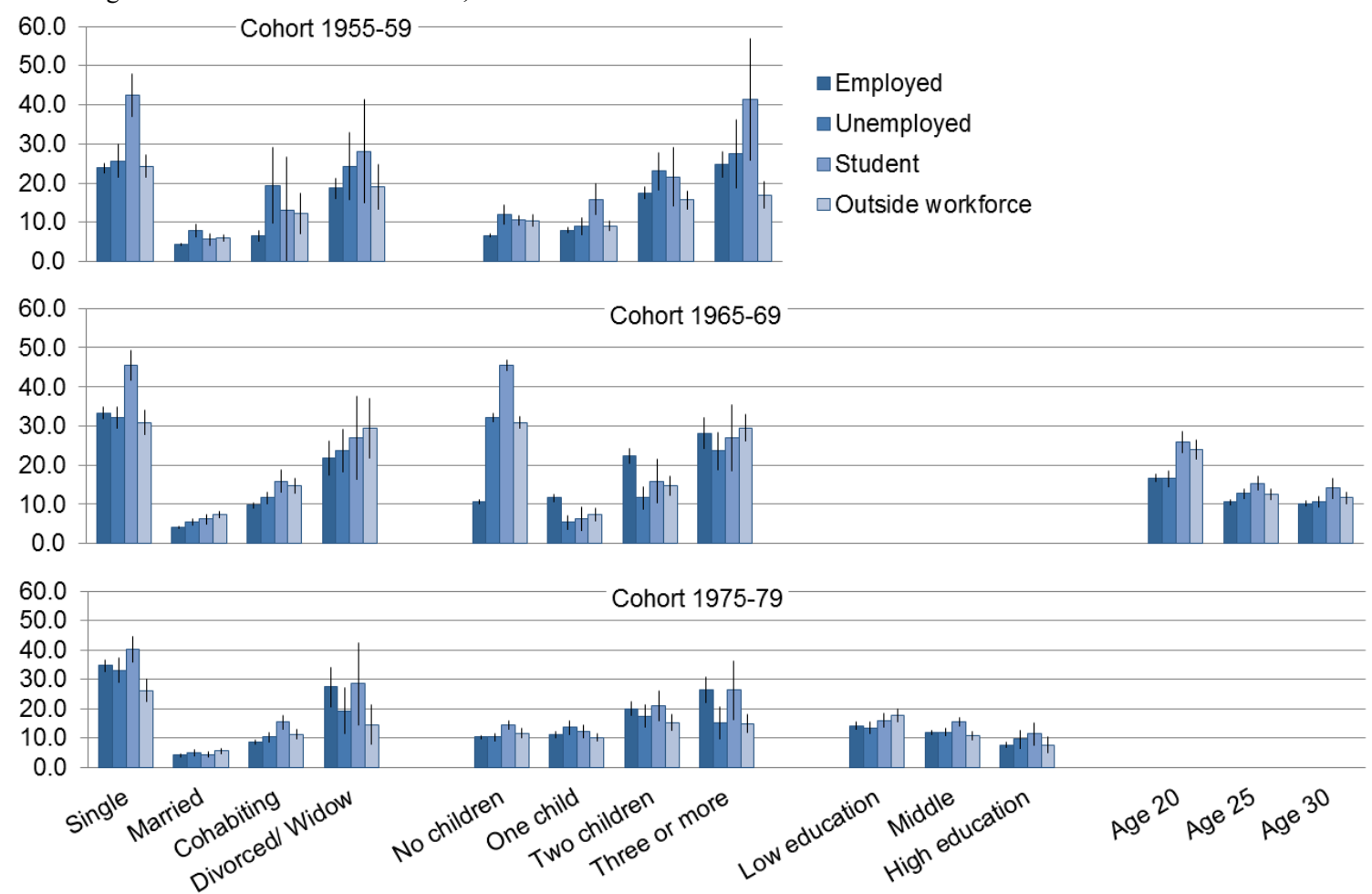

Notes: As information on cohabitation has only been available since 1987 in the registers, its estimates for the earliest cohort are only indicative.

The probability of abortion was over 20 percent among single women in all labour force status groups in the 1950s cohort (Figure 2). The probability was markedly lower (less than 10 percent) for married women in all labour force status groups. Married and cohabiting women had the highest probability within the respective relationship status group 
if they were unemployed, whereas for single women the probability was highest among students. Women who had 0-2 children were less likely to terminate a pregnancy if they were employed compared to other labour status groups, but women with at least three children were less likely to terminate a pregnancy if they were outside the workforce.

The probability of abortion was more than 30 percent among single women in all labour force status groups in the 1960s cohort, compared to less than 10 percent among married women (Figure 2). Childless women who were employed had markedly lower probability of abortion than other childless women (10 percent compared to more than 30 percent), but among women with one to two children those who were employed had the highest probability. The interaction between age and labour force status revealed that at age 20 students and those outside the workforce had the highest probability of abortion, but at the differences were small in later ages. In the 1970s cohort the differences between different labour status groups were smaller than in the other two cohorts.

\section{Discussion}

When the likelihood of abortion was analysed among all women, unemployed women had a high likelihood of abortion in all cohorts in age-controlled and multivariate models. This may be because they wish to postpone their childbearing due to the uncertainty of their economic situation and due to the possible difficulties childbearing may impose on finding work later on (Becker 1991; Hrdy 1999; Kreyenfeld 2010; Sutela 2013). This was further supported by the interaction effects showing that especially women without partners (single, divorced or widowed) had a markedly higher likelihood of abortion if they were unemployed, but the association was less strong for cohabiting and married women, who were perhaps able to count on their partner's support.

Contrary to findings showing an increase in educational differences in the likelihood of abortion over time among Finnish women (Väisänen 2015), it seems like the importance of labour force participation in explaining the likelihood of abortion has decreased over time. Although being unemployed or outside workforce was positively associated with the likelihood of abortion in the two earliest cohorts, these differences were modest in the 1970s cohort in particular when only pregnant women were studied. Perhaps access to and knowledge of family planning services depends less on labour force status and more on other characteristics of the women among the later than the earlier cohorts.

When only pregnant women were analysed, the unemployed had a higher likelihood of abortion than employed women in the 1950s and 1960s cohorts, but no marked difference was found in the 1970s cohort even when interacted with other covariates: unemployed women had similar or lower likelihood than employed women regardless of their relationship status, age, education or parity in the 1970 s cohort indicating that other factors than labour force participation were more important in predicting the likelihood of abortion for these women. 
Pregnancy decision-making is likely to be affected by the macro-economic situation (Sobotka, Skirbekk, and Philipov 2011; Testa and Basten 2014). During difficult times when the prospects of finding a job are not good, many women may wish to postpone childbearing until the economic prospects have improved. Interestingly, employed parous women had higher likelihood of abortion than other women with children in the 1960s cohort, but among women with no children it was the other way around. Perhaps women with families were particularly concerned about opportunity costs of childbearing in this cohort, where women were in their late 20 s and 30 s during the severe recession years of the 1990s.

When all women were studied, students were not likely to have an abortion, but the association reversed when the analysis was restricted to women who experienced a pregnancy. This may indicate that students have high motivation to avoid pregnancy — perhaps they want to make sure that they will be able to finish their studies or are concerned about their financial situation - and thus use contraceptives efficiently (Frost, Singh, and Finer 2007; Moreau et al. 2013). Hence, they have low likelihood of abortion when compared to all women due to low number of pregnancies overall. However, should a pregnancy occur, the motivation to avoid childbearing remains strong and they often decide to terminate the pregnancy.

A study in Germany showed that women with high education tend to avoid childbearing if they are in an uncertain economic position whereas the opposite is true for women with low education (Kreyenfeld 2010). The abortion behaviour of Finnish women does not seem to support this hypothesis: in most of the models labour market status did not interact with education and even when it did, the differences were small. However, this finding does not imply that the hypothesis is untrue-perhaps the lack of differences was due to differences in contraceptive use patterns.

The results of the study may have been affected by changes in family policies during the study period. Since the mid-1980s a home care allowance system has permitted a parent to stay at home without losing his or her job until their youngest child is three years old. At the same time, universal right to day-care of children under age three since 1985 (under age seven since 1996) facilitated combining work and family life (Haataja 2006; Vikat 2004). These changes have probably changed the composition of the population in the different labour market participation groups. For instance, women with permanent jobs are more likely to use a longer period of the home care allowance before returning to work after childbearing, whereas those in a more uncertain position return to work sooner (Salmi, Lammi-Taskula, and Närvi 2009). Before the allowance was introduced, it may have been women in the more precarious labour market position who stayed home for longer periods of time. These policy changes were likely to contribute to some of the cohort differences observed in this study.

There were limitations in this study. Most importantly, pregnancy intentions of the women were not known although it would have given new insight into the analysis. Also, women outside the workforce were a somewhat heterogeneous group including 
for instance, pensioners and those in military service, which may reduce the reliability of the variable, but given that my sample consists of women in reproductive age, most of these women were probably taking care of their children at home. Information on spontaneous abortions was not included in this study, as that information is not complete in the registers which only include miscarriages that required a medical intervention. However, as the focus of the study was in situations in which women decided to terminate a pregnancy, it does not compromise the results.

The strengths of the study include the reliable dataset which does not suffer from dropout or underreporting of abortions. Also, the topic of this study has not been widely studied previously.

Future studies should collect nationwide data on pregnancy intentions and contraceptive use patterns in Finland. At the moment representative data on these topics is not available. This makes it difficult for researchers to identify the motivations behind the decisions to terminate a pregnancy. Future research should focus on whether the socioeconomic patterns observed in this study were due to differences in contraceptive use, different attitudes towards abortion, economic concerns, career aspirations, or some other reasons.

\section{Acknowledgements}

Many thanks to Professor Mike Murphy for helpful comments and Professor Mika Gissler and Dr Markus Jokela for their expertise help with obtaining the data set. This work was supported by the Economic and Social Research Council under Grant number ES/J00070/1. I am grateful to Statistics Finland and the National Institute of Health and Welfare for the permissions (TK53-162-11 and THL/173/5.05.00/2011 respectively) to use these data.

\section{References}

Bankole, Akinrinola, Susheela Singh, and Taylor Haas. (1998). Reasons Why Women Have Induced Abortions: Evidence from 27 Countries. International Family Planning Perspectives 24 (3), 117-52. doi:10.2307/3038208.

Becker, Gary S. (1991). A Treatise on the Family. Enlarged ed. Cambridge, Mass, London: Harvard University Press.

Coast, Ernestina, Alison Norris, Ann Moore, and Emily Freeman. (2014). Trajectories to Abortion and Abortion-Related Care: A Conceptual Framework. In IUSSP international seminar on decisionmaking regarding abortion. Nanyuki, Kenya: IUSSP. http://www.iussp.org/.

Denisov, Boris P., Victoria I. Sakevich, and Aiva Jasilioniene. (2012). Divergent Trends in Abortion and Birth Control Practices in Belarus, Russia and Ukraine. PLoS ONE 7 (11), e49986. doi:10.1371/ journal.pone.0049986.

Frost, Jennifer J., Susheela Singh, and Lawrence B. Finer. (2007). Factors Associated with Contraceptive Use and Nonuse, United States, 2004. Perspectives on Sexual and Reproductive Health 39 (2), 90-99. doi:10.1363/3909007. 
Gissler, Mika. (2010). Registration of Births and Induced Abortions in the Nordic Countries. Finnish Yearbook of Population Research XLV: 171-78.

Haataja, Anita. (2006). Nordic breadwinner-caretaker models - comparison of Finland and Sweden. 43. Reports of the Ministry of Social Affairs and Health, Finland. Helsinki: the Ministry of Social Affairs and Health. http://www.stm.fi/c/document_library/get_file?folderId=28707\&name=DL FE-3693.pdf\&title=Pohjoismainen_ansaitsija_hoivaajamalli_fi.pdf.

Heikinheimo, Oskari, Mika Gissler, and Satu Suhonen. (2008). Age, Parity, History of Abortion and Contraceptive Choices Affect the Risk of Repeat Abortion. Contraception 78 (2), 149-54. doi:10.1016/j.contraception.2008.03.013.

Hrdy, Sarah Blaffer. (1999). Mother Nature: Natural Selection and the Female of the Species. London: Chatto \& Windus.

Jones, Rachel K., Jacqueline E. Darroch, and Stanley K. Henshaw. (2002). Patterns in the Socioeconomic Characteristics of Women Obtaining Abortions in 2000-2001. Perspectives on Sexual and Reproductive Health 34 (5), 226-35. doi:10.2307/3097821.

Jones, Rachel K., and Kathryn Kost. (2007). Underreporting of Induced and Spontaneous Abortion in the United States: An Analysis of the 2002 National Survey of Family Growth. Studies in Family Planning 38 (3), 187-97. doi:10.1111/j.1728-4465.2007.00130.x.

KELA. (2015). Vanhempainraha työttömälle, opiskelijalle ja kuntoutujalle. http://www.kela.fi/vanhempainraha_tyottomalle-ja-opiskelijalle.

Knudsen, Lisbeth B, Mika Gissler, Soley S Bender, Clas Hedberg, Ulla Ollendorff, Kajsa Sundström, Kristina Totlandsdal, and Sigridur Vilhjalmsdottir. (2003). Induced Abortion in the Nordic Countries: Special Emphasis on Young Women. Acta Obstetricia et Gynecologica Scandinavica $82(3), 257-68$.

Kreyenfeld, Michaela. (2010). Uncertainties in Female Employment Careers and the Postponement of Parenthood in Germany. European Sociological Review 26 (3), 351-66. doi:10.1093/esr/jcp026.

Lainiala, Lassi. (2014). Perhepolitiikka kriisin aikana [Family policy at the time of crisis]. Perhebarometri. Helsinki: Family Federation of Finland (Väestöliitto). http://vaestoliitto-fi-bin.directo. fi/@Bin/2c0e377dc310f936b7de20dc745b0ee4/1422531423/application/pdf/3720143/Perhebarometri\%202014_web.pdf.

Lehti, Venla, Andre Sourander, Päivi Polo-Kantola, Lauri Sillanmäki, Tuula Tamminen, and Kirsti Kumpulainen. (2013). Association between Childhood Psychosocial Factors and Induced Abortion. European Journal of Obstetrics \& Gynecology and Reproductive Biology 166 (2), 190-95. doi:10.1016/j.ejogrb.2012.10.017.

Moreau, C., K. Hall, J. Trussell, and J. Barber. (2013). Effect of Prospectively Measured Pregnancy Intentions on the Consistency of Contraceptive Use among Young Women in Michigan. Human Reproduction (Oxford, England) 28 (3), 642-50. doi:10.1093/humrep/des421.

Niinimäki, Maarit, Anneli Pouta, Aini Bloigu, Mika Gissler, Elina Hemminki, Satu Suhonen, and Oskari Heikinheimo. (2009). Frequency and Risk Factors for Repeat Abortions after Surgical Compared with Medical Termination of Pregnancy. Obstetrics and Gynecology 113 (4), 845-52. doi:10.1097/AOG.0b013e31819cae06.

Official Statistics of Finland, OSF. (2012). Labour Force Survey [e-Publication]. Time Series Data 2002-2011 2011, 3 Families and Work in 2011. Helsinki: Statistics Finland. http://www.stat.fi/til/ tyti/2011/15/tyti_2011_15_2012-11-06_kat_003_en.html.

Official Statistics of Finland., OSF (2013a). Concepts and Definitions - Main Type of Activity. http:// www.stat.fi/meta/kas/tyovoima_ulkopu_en.html.

Official Statistics of Finland, OSF. (2013b). Työssäkäynti [verkkojulkaisu]. [Labour force participation (e-publication)]. March 22. http://www.stat.fi/til/tyokay/2011/02/tyokay_2011_02_2013-03-22_ laa_001_fi.html.

Population Register Centre. (2015). Population Information System - Population Register Centre. http://www.vrk.fi/default.aspx?id=39. 
Rasch, V., T. Gammeltoft, L. B. Knudsen, C. Tobiassen, A. Ginzel, and L. Kempf. (2007). Induced Abortion in Denmark: Effect of Socio-Economic Situation and Country of Birth. The European Journal of Public Health 18 (2), 144-49. doi:10.1093/eurpub/ckm112.

Regushevskaya, Elena, Tatiana Dubikaytis, Made Laanpere, Minna Nikula, Olga Kuznetsova, Elina Haavio-Mannila, Hele Karro, and Elina Hemminki. (2009). Risk Factors for Induced Abortions in St Petersburg, Estonia and Finland. Results from Surveys among Women of Reproductive Age. The European Journal of Contraception \& Reproductive Health Care: The Official Journal of the European Society of Contraception 14 (3), 176-86. doi:10.1080/13625180902916038.

Rossier, Clémentine, François Michelot, and Nathalie Bajos. (2007). Modeling the Process Leading to Abortion: An Application to French Survey Data. Studies in Family Planning 38 (3), 163-72.

Salmi, Minna, Johanna Lammi-Taskula, and Johanna Närvi. (2009). Perhevapaat ja työelämän tasaArvo. [Parental Leave and the Gender Equality of the Labour Market.]. Työ Ja Yrittäjyys 24/2009. Helsinki: Työ- ja elinkeinoministeriö.

Sedgh, Gilda, Susheela Singh, Iqbal H Shah, Elisabeth Åhman, Stanley K Henshaw, and Akinrinola Bankole. (2012). Induced Abortion: Incidence and Trends Worldwide from 1995 to 2008. The Lancet 379 (9816), 625-32. doi:10.1016/S0140-6736(11)61786-8.

Sobotka, Tomáš, Vegard Skirbekk, and Dimiter Philipov. (2011). Economic Recession and Fertility in the Developed World. Population and Development Review 37 (2), 267-306. doi:10.1111/j.17284457.2011.00411.x.

Statistics Finland. (2011). Statistics Finland - About Statistics - Educational Structure of Population. http://www.stat.fi/meta/til/vkour_en.html.

Sutela, Hanna. (2013). Määräaikainen Työ Ja Perheellistyminen Suomessa 1984-2008 [Temporary Contracts and Family Formation in Finland 1984-2008]. 259. Research Reports. Helsinki: Statistics Finland. http://www.stat.fi/tup/julkaisut/tiedostot/julkaisuluettelo/ytut_259_201300_2013_10310_ net.pdf.

Testa, Maria Rita, and Stuart Basten. (2014). Certainty of Meeting Fertility Intentions Declines in Europe during the 'Great Recession.' Demographic Research 31 (September), 687-734. doi:10.4054/ DemRes.2014.31.23.

Väisänen, Heini. (2015). The Association between Education and Induced Abortion for Three Cohorts of Adults in Finland. Population Studies, October, 1-16. doi:10.1080/00324728.2015.1083608.

Väisänen, Heini, and Markus Jokela. (2010). Fertility after Induced Abortion: A Register-Based Study in Finland 2000-2008. Finnish Yearbook of Population Research XLV: 25-44.

Vikat, Andres. (2004). Women's Labor Force Attachment and Childbearing in Finland. Demographic Research Special 3 (April), 177-212. doi:10.4054/DemRes.2004.S3.8.

Vuori, Anna, and Mika Gissler. (2013). Perinatal Statistics: Parturients, Deliveries and Newborns 2012. Official Statistics of Finland. Helsinki: National Institute for Health and Welfare. http://urn. fi/URN:NBN:fi-fe201309276347.

Williams, Richard. (2012). Using the Margins Command to Estimate and Interpret Adjusted Predictions and Marginal Effects. The Stata Journal 12 (2), 308-31. 